\title{
A NEW SPECIES AND A NEW GENUS OF RESTIONACEAE FROM TASMANIA
}

\author{
L. A. S. Johnson \& B. G. BRigGS
}

(Accepted for publication 22.3.1985)

\begin{abstract}
Johnson, L. A. S. \& Briggs, B. G. (National Herbarium of New South Wales, Royal Botanic Gardens, Sydney, Australia 2000) 1986. A new species and a new genus of Restionaceae from Tasmania. Telopea 2(6): 737-740 - Winifredia sola (genus et species nov.) from south-west Tasmania is described. Restio glaber (Rodway) L. Johnson \& B. Briggs (comb. et stat. nov.) is recognized as a species distinct from $R$. monocephalus; the generic position of this and allied species referred to Restio will be reviewed elsewhere.
\end{abstract}

A name is needed for a distinctive Tasmanian taxon that is undescribed and a name at species rank is needed for another that has been named only in varietal rank. The forthcoming treatment of the Monocotyledons by $\mathrm{Dr}$ Winifred Curtis and Mr Dennis Morris in The Student's Flora of Tasmania gives reason for providing names at this stage, in advance of resolution of the generic classification of Australian Restionaceae as a whole.

\section{Winifredia L. Johnson \& B. Briggs, gen. nov.}

Planta dioica. Culmi chlorenchymate haud interrupto (sine cellulis columniformibus et sine sclerenchymate interchlorenchymatico). Vaginae praesentes persistentesque. Spiculae masculinae multiflorae. Flores masculini tepalis 6 et staminibus 3 antheris unilocularibus exsertis instructi. Grana pollinis poro irregulari magnoque instructa. Flores foeminei haud in spiculis, unusquisque bracteolis 2 et tepalis 6 instructus. Ovarium uniloculare sed fortasse dehiscens. Rami styli 3, usque ad basin separati. Ovulum 1.

Dioecious. Culms with uninterrupted chlorenchyma (without pillar cells or sclerenchyma girders). Sheaths present, persistent. Male spikelets manyflowered. Male flowers with 6 tepals and 3 stamens with exserted unilocular anthers. Pollen with large irregular pore (centrolepidoid). Female flowers not arranged in spikelets but with 2 bracteoles and 6 tepals. Ovary unilocular but perhaps dehiscent. Style branches 3 , separate to the base. Ovule 1.

TYPE SPECIES: Winifredia sola L. Johnson \& B. Briggs.

Winifredia is named in honour of Dr Winifred M. Curtis who collected material of this genus, drew our attention to it, and whose work has added so greatly to knowledge of the Tasmanian flora.

\section{Distribution: South-west Tasmania.}

The relationships of Winifredia need further consideration and will be discussed elsewhere in conjunction with a phylogenetic analysis of the family. It has much the facies and culm anatomy of the majority of eastern Australian species that have generally been referred to Restio (i.e. to the species constituting 'pseudo-Restio a', Johnson \& Briggs 1981, 1983), but differs in that the female flowers are accompanied by bracteoles and not organized into spikelets, as well as in the unilocular ovary. 
Winifredia sola $L$. Johnson \& B. Briggs, sp. nov.

Rhizoma elongatum. Culmi simplices, glabri, robusti. Vaginae appressae vel laxiusculae. Spiculae masculinae 12-25-florae. Tepala florum masculinorum anguste lanceolata, acuminata, ea lateralia carinata; tepalis interioribus angustioribus. Flores foeminei tepalis eis masculinorum similibus et bracteolis subaequalibus carinatis instructi.

Rhizome elongated, stout, to $30 \mathrm{~cm}$ long, 3-5 mm diam., densely villous with white hairs, bearing broadly deltoid scale-leaves. Cataphylls pale, scarious, mostly broad-elliptic. Culms simple, glabrous, to $30 \mathrm{~cm}$ tall, $2-3 \mathrm{~mm}$ diam., smooth when fresh but often indistinctly and irregularly striate when dry; chlorenchyma of a single uninterrupted layer of palisade cells, pith cavity large, stomates superficial. Sheaths 4-7, persistent, appressed or slightly lax, 5-20 mm long; truncate, scarious, pale, glabrous except for the finely ciliate distal margin. Subtending inflorescence bracts: lower ones similar to sheaths, upper ones lanceolate-acuminate, with male spikelets or female flowers singly or several in the axils. Male spikelets ovoid, 4-7 mm long, on pedicels to $12 \mathrm{~mm}$ long, with c. 12-25 flowers; glumes lanceolate, acuminate, c. $3.5 \mathrm{~mm}$ long, red-brown weathering to grey-brown, with narrow membranous and shortly fimbriate margins. Male flowers: outer tepals narrow-lanceolate, acuminate, c. $3 \mathrm{~mm}$ long, the laterals keeled; inner tepals shorter, membranous, subacute; stamens exserted. Female flowers: shortly petiolate; bracteoles 2, subequal, keeled, 3-4 $\mathrm{mm}$ long; tepals similar to those of males; staminodes 3; ovary unilocular, 3 -angled with thickened pale ridges at the angles, ovule 1, pendulous from near the summit of the loculus. Fruits and seeds not seen, but the thickened ovary sutures suggest that the ovary is dehiscent.

HolotyPE: Near Spring River, north of Port Davey, Tasmania, c. $43^{\circ} 12^{\prime} \mathrm{S}$ $146^{\circ} 03^{\prime} \mathrm{E}$, S. J. Jarman, 2 Feb. 1979, o (HO 37333). Isotype (NSW 154424).

The specific epithet is from the Latin solus meaning lonely, unfrequented or single, referring to the species' occurrence in a remote unpopulated region and also to its monotypic status.

Distribution: On wet peaty soil in heathy sedgeland or with Gymnoschoenus sphaerocephalus ('Button Grass') in the general vicinity of Port Davey, south-west Tasmania $\left(42^{\circ} 50^{\prime} \mathrm{S} 145^{\circ} 35^{\prime} \mathrm{E}\right.$ to $\left.43^{\circ} 25^{\prime} \mathrm{S} 146^{\circ} 10^{\prime} \mathrm{E}\right)$. $W$. sola is reported to be very local in distribution but plentiful where found. Since its known range is very restricted, its conservation status warrants investigation.

Specimens examined: Tasmania: Giblin Valley (E. of Lawson Range), $S . J$. Jarman, 20.1.1979, ơ (HO 37331), \& (HO 37329, 37330); near Spring R., N. of Port Davey, S. J. Jarman, 2.2.1979, o (HO, NSW 154425); Port Davey, $W . M$. Curtis, 12.2.1971, ơ (HO 37332); Melaleuca airstrip, Melaleuca Inlet, Bathurst Harbour, M. Brown, 13.3.1981, \& (NSW 154426); Moth Creek, Melaleuca Inlet, Port Davey, M. Davis 1233, -, o, \& (HO 37334); Bathurst Harbour, around Claytons, S. J. Jarman 56, 13.3.1980, ơ (HO 33906).

Restio glaber (Rodway) L. Johnson \& B. Briggs, stat. nov.

Basionym: Restio oligocephalus F. Muell. var. glaber [as 'glabrum'] Rodway, Tasm. Fl.: 236 (1903). [R. oligocephalus F. Muell. is a synonym of $R$. monocephalus $\mathrm{R}$. Br.] 
LeCTOTYPe (here designated): Kingston, $42^{\circ} 58^{\prime} \mathrm{S} 147^{\circ} 20^{\prime} \mathrm{E}$, L. Rodway, Oct. 1894, \% (HO 25143). The sheet bears material of both male and female plants; the female is designated as lectotype, the male becoming a lectoparatype.

Rhizome slender, elongated, $2-3 \mathrm{~mm}$ diam., villous with pale hairs and bearing very broadly triangular scales. Cataphylls pale brown or reddish brown, oblong to oblong-spathulate; upper ones lax, $2-3 \mathrm{~cm}$ long, with membranous auricles and a mucro (reduced lamina) c. $2 \mathrm{~mm}$ long. Culms simple, smooth, $7-25(-50) \mathrm{cm}$ tall, very slender, $0.7-1.0 \mathrm{~mm}$ diam., slightly flattened, usually grooved on one side when dry, with a single sheath, the lower internode mostly 2 or more times as long as the upper internode; chlorenchyma uninterrupted, of $2(-4)$ layers of palisade cells, thicker radially between the outer vascular bundles, pith cavity lacking, stomates superficial, radial walls of epidermal cells not markedly thickened or undulate. Sheaths narrow-oblong, 3-20 mm long, with membranous auricles and a mucro c. $2 \mathrm{~mm}$ long. Spikelets solitary, sessile or shortly pedicellate, male and female similar, ovoid, 5-7 mm long, with 4-10 very shortly pedicellate flowers; subtending bract inconspicuous, e. $3 \mathrm{~mm}$ long; lower glumes empty. Glumes ovate, 3-3.5 mm long, blackish brown, glabrous, slightly glossy, with pale membranous margins. Male flowers: outer tepals linear-lanceolate, c. $2.5 \mathrm{~mm}$ long, inner tepals membranous, c. $2 \mathrm{~mm}$ long. Female flowers: tepals all \pm equal, narrow-ovate, c. $2.5 \mathrm{~mm}$ long; staminodes 3; ovary bilocular, compressed; style branches 2 , stigmatic almost to base. Capsule obovate, dorsiventrally compressed, c. $1.5 \mathrm{~mm}$ long, the sutures pale and thickened. Seed not seen.

We are reviewing the generic position of the Australian species customarily referred to Restio. Together with the majority of other Australian genera, they differ consistently from African Restionaceae in culm anatomy and pollen. However, the Australian 'Restio' species can be divided into two main groups on anatomical features (Cutler 1969, 1972; Johnson \& Briggs 1981, 1983). Pending a review of all relevant taxa, we have retained this species in Restio rather than separating it from its allies.

$R$. glaber appears to be most closely allied to $R$. monocephalus, but is distinct in its more slender culms with fewer internodes, narrower cataphylls and sheaths, longer cataphylls and smaller floral parts, as well as in the relatively broader tepals that are glabrous and less rigid.

Distribution: South-east Tasmania, very discontinuously (so far as known) from west of Mt Field National Park to Sandford and Blackmans Bay south of Hobart, and on Bruny Island. On sandy heaths. The population at the Type area is endangered by urban development, but others seem more secure.

SPecimens eXAmined: Mt Wright, c. $14 \mathrm{~km}$ WNW. of Mt Field West, $M$. Brown NSW 154428, 14.10.1981, . (NSW); Sandford, M. Allen NSW 154586, 9.6.1978, o" (NSW); Longley (c. $18 \mathrm{~km} \mathrm{~S}$. of Hobart), M. Allen, -, o, \& (HO 37344); Longley, A. H. S. Lucas NSW 47871, 3.1925, \& (NSW); Browns River, J. B. Cleland, 30.1.1928 (AD); Kingston, A. Ratkowsky, 16.10.1973, o" (HO 37337); Boronia Hill, D. A. \& A. V. Ratkowsky 1480, -, o' (NSW), 909, 12.11.1973, ơ (NSW); Blackmans Bay, W. M. Curtis, 26.9.1943, o' (HO 37335), 27.9.1943, o" (HO), 10.1943, o" (HO 37338); Bruny I., McNeil, 9.1975, ơ (HO 37339 p.p.); Bruny I., W. M. Curtis, 26.9.1978, o, o (HO 37340); Bruny I., 17.5 $\mathrm{km}$ by road S. of Barnes Bay, B. Briggs 7055, 10.11.1980, $\sigma^{\circ}$ (NSW, HO), 7054, 10.11.1980, o (NSW, HO); South Bruny, M. Allan, 25.8.1975, ơ (HO 37342). 


\section{ACKNOWLEDGMENTS}

We are greatly indebted to Dr Winifred Curtis, who drew our attention to the taxa treated here and who kindly provided material for study. Dr Jean Jarman and Dr Michael Brown gave valued assistance by making special collections of Winifredia.

\section{REFERENCES}

Cutler, D. F. (1969). 'Anatomy of the Monocotyledons'. IV. Juncales. (Clarendon Press: Oxford).

Cutler, D. F. (1972). Vicarious species of Restionaceae in Africa, Australia and South America. In Valentine, D. H. (Ed.), 'Taxonomy, Phytogeography and Evolution' (Academic Press: London) pp. 78-83.

Johnson, L. A. S. \& Briggs, B. G. (1981). Three old southern families Myrtaceae, Proteaceae and Restionaceae. In Keast, A. (Ed.), 'Ecological Biogeography of Australia' (W. Junk: The Hague) vol. 1, pp. 428-469.

Johnson, L. A. S. \& Briggs, B. G. (1983). Restionaceae. In Morley, B. D. \& Toelken, H. R. (Eds), 'Flowering Plants in Australia' (Rigby: Adelaide) pp. 371-373.

Manuscript received 11.4.1984. 